\title{
Erratum to: Complete genome sequences of Geobacillus sp. Y412MC52, a xylan- degrading strain isolated from obsidian hot spring in Yellowstone National Park
}

Phillip Brumm ${ }^{1 *}$, Miriam L. Land ${ }^{2}$, Loren J. Hauser², Cynthia D. Jeffries ${ }^{3}$, Yun-Juan Chang ${ }^{3}$ and David A. Mead ${ }^{4}$

After publication of this study [1], the authors noticed that GenBank accession number is incorrect. The correct GenBank accession number is CP002442.

\section{Author details}

${ }^{1}$ C5.6 Technologies Inc, Middleton, WI, USA. ${ }^{2}$ Oak Ridge National Laboratory, Oak Ridge, TN, USA. ${ }^{3}$ Bioscience Division, Los Alamos National Laboratory,

Los Alamos, NM, USA. ${ }^{4}$ Lucigen Corporation, Middleton, WI, USA.

Received: 7 December 2015 Accepted: 7 January 2016

Published online: 26 January 2016

\section{References}

1. Brumm P, Land LL, Hauser JL, Jeffries DC, Chang YJ, Mead DA. Complete genome sequences of Geobacillus sp. Y412MC52, a xylan-degrading strain isolated from obsidian hot spring in Yellowstone National Park. Stand Genomic Sci. 2015;10:81.

Submit your next manuscript to BioMed Central and we will help you at every step:

- We accept pre-submission inquiries

- Our selector tool helps you to find the most relevant journal

- We provide round the clock customer support

- Convenient online submission

- Thorough peer review

- Inclusion in PubMed and all major indexing services

- Maximum visibility for your research

Submit your manuscript at www.biomedcentral.com/submit

\section{() Biomed Central}

(c) 2016 Brumm et al. Open Access This article is distributed under the terms of the Greative Commons Attribution 4.0 International License (http://creativecommons.org/licenses/by/4.0/), which permits unrestricted use, distribution, and reproduction in any medium, provided you give appropriate credit to the original author(s) and the source, provide a link to the Creative Commons license, and indicate if changes were made. The Creative Commons Public Domain Dedication waiver (http://creativecommons.org/publicdomain/zero/1.0/) applies to the data made available in this article, unless otherwise stated. 